\title{
FLOWERS FOR CANCER TREATMENT: FROM BEAUTY TO DUTY
}

\section{Flores para el tratamiento del cáncer: de la belleza al deber}

\author{
iD Jorge L. Gutierrez-Pajares ${ }^{1}$ (iD Amr Abdelkhalek ${ }^{2}$ \\ 'Le Cordon Blue University, Peru. \\ ${ }^{2}$ Horticultural Crops Technology Department, National Research Centre, Dokki, Giza, Egypt. \\ Correspondencia: \\ Dr. Jorge Gutiérrez Pajares \\ Jorge.gutierrez@ulcb.edu.pe
}

\section{ABSTRACT}

Cancer is a worldwide disease that affects millions of people every year. Although there are several approved chemotherapeutic drugs for cancer treatment, there is s constant search for new molecules. This search is supported by the need of new molecules that could target cancer cells specifically reducing side effects or that could act synergistically with approved anticancer drugs. In this review, research on flower extracts and flower-derived molecules is presented.

Keywords: Cancer, flower extracts, flower-derived molecules

\section{RESUMEN}

El cáncer es una enfermedad mundial que afecta a millones de personas cada año. Aunque existen varios fármacos quimioterapéuticos aprobados para el tratamiento del cáncer, existe una búsqueda constante de nuevas moléculas. Esta búsqueda está respaldada por la necesidad de nuevas moléculas que puedan apuntar a las células cancerosas reduciendo específicamente los efectos secundarios o que puedan actuar de manera sinérgica con los medicamentos contra el cáncer aprobados. En esta revisión, se presenta la investigación sobre extractos de flores y moléculas derivadas de flores.

Palabras clave: Cáncer, extractos de flores, moléculas derivadas de flores 


\section{INTRODUCTION}

Cancer is a chronic disease that, in a simple idea, involves the uncontrolled proliferation of abnormal cells as a consequence of acquired somatic mutations. However, in addition to proliferation, cancer cells acquire other important features such as insensitivity to growth-inhibitory signals, evasion of programmed cell death, sustained angiogenesis and tissue invasion and metastasis (Hanahan and Weinberg , 2011). All of these features favor the growth of the tumor and the ability to reach other organs, thus, increasing its progression of malignancy.

Cancer is a major disease that has been responsible for 9.6 million cancer deaths around the world in 2018 (Bray et al., 2018). Among them, cancer of breast and lung are the most prevalent in female and males, respectively (Bray et al., 2018).

Since the high proliferative status of cancer cells is the most common characteristic of these malignantcells, many drugs have been developed to attack different aspects of cell division. In particular, a combination of anticancer drugs have been suggested to improve treatment efficacy (Blagosklonny, 2004).

In order to develop novel anticancer drugs, scientists began testing natural compounds present in plants. One of the most well-known plant-derived anticancer compounds is taxol, also known as paclitaxel. Taxol was isolated from the bark of Taxus brevifolia and demonstrated to have anticancer activity in 1966 (Wani et al., 1971) after eleven years of dedication of the U.S. National Cancer Institute for screening novel compounds against this disease (Goodman, Walsh, and Walsh, 2001). By the year 1992, the U.S. Food and Drug Administration office approved the use of taxol as an chemotherapeutic drug (Goodman et al., 2001). By 2010, more than 800 anticancer agents were under clinical development (Arrondeau et al., 2010) and from 1949 to 2014 the FDA has approved 150 compounds for cancer treatments (Sun et al., 2017).
Considering that the are many metabolites in the plant world that are not known for their anticancer activity, there is a constant interest in researching of plant's metabolites to identify novel chemotherapeutics molecules (Tan, Gyllenhaal, and Soejarto, 2006). In this review, we will focus on the investigations of flowers as a source of metabolites against cancer.

\section{Traditional use of flowers for cancer treatment} Traditional plant utilization by indigenous cultures is a useful first step for drug discovery since information of herbal remedies by indigenous people include a vast period of time for selecting the optimal plant (and its parts) and defining the best method of preparation to achieve a cure.

In Palestine, there is a variety of plant species used as anticancer agents (Jaradat et al. 2016). Among them, flowers represent around 10\% of the used part of medicinal plants (Table 1). In another study, hospitalized cancer patients in Morocco were interviewed to collect ethnopharmacological information where flowers used for cancer treatment reached around 2\% of the total used parts of herbal remedies (Samouh et al., 2019)

\section{Extracts from flowers with anticancer effect}

The use of extracts is the first step towards finding a potential fraction with anticancer effect. Aqueous and organic chemicals are the most common solvents used to extract molecules from plants. A summary of in vitro and in vivo studies with FE is shown in Tables 2 and 3 , respectively. The aqueous extract of the flower of Butea monosperma promoted the cell cycle arrest in $\mathrm{G} 1$ and apoptotic response of hepatoma cells with marginal effect on immortalized mouse hepatocytes in vitro (Choedon, Shukla, and Kumar 2010). Importantly, this extract increased the apoptosis of hepatocytes of the HBV-related X15-myc transgenic mice after 12-month treatment period. In another study, the aqueous flower extract (FE) of Hibiscus rosa-sinensis decreased cell viability of estrogen-receptor positive and triple-negative breast cancer cell 
lines with doses equal or higher than $2000 \mu \mathrm{g} /$ $\mathrm{mL}$ causing oxidative stress (Nguyen et al., 2019).

Using the MTT assay to evaluate cell viability, Al-Oqail et al. determined that the petroleum extract from the flower of Aloe perryi had a potent inhibitory effect of cancer cell proliferation assaying on a seven cell line panel (HepG2, HCT116, MCF-7, A549, PC-3, HEp-2 and HeLa) (Al-Oqail et al., 2016). A methanolic extract of the flowers of Iris pseudopumila inhibited the proliferation of large lung cell carcinoma CORL-23 and amelanotic melanoma C32 cells in vitro (Conforti et al., 2009). Similarly, the methanolic extract of Rhododendron arboretum was reported to have a slightly effect on the growth proliferation of breast, cervical and lung epidermal cancer cells in vitro (Gautam et al. 2020). In this report, a concentration of $500 \mu \mathrm{g} / \mathrm{mL}$ was needed to inhibit cancer survival in a significant manner for all tested cell lines (Gautam et al., 2020).

The methanolic extract of the flowers of Allium atroviolaceum inhibited the proliferation of breast cancer cells but not in non-transformed mouse fibroblasts (Khazaei, Abdul Hamid, et al., 2017). This observation was accompanied with an A. atroviolaceum-induced arrest of cell cycle and increase of apoptosis. In addition, this group reported that the FE of A. atroviolaceum induced the apoptosis of cervical cancer cells by downregulating $\mathrm{BCl}-2$ and activating both caspase-9 and -3 (Khazaei, Ramachandran, et al., 2017).

Another approach to present an anticancer activity is by contributing to the cancer toxicity effect of a chemotherapeutic drug. The combination of flower-derived novel compounds with well-established chemotherapeutic drugs may inhibit cancer cell proliferation with less amount of drug as possible to diminish then undesirable side effects. It has been reported that extract of flower of Dimocarpus longan acts synergistically with 5-fluorouracil to inhibit the in vitro proliferation of the colon cancer cells HT29 and Colo 320DM (Chen et al., 2020). In a similar manner, the combination of the FE of $\mathrm{A}$. atroviolaceum with tamoxifen (Khazaei, Abdul Hamid, et al., 2017) or doxorubicin exerted a significant synergistic anticancer effect in breast and cervical cancer cells in vitro, respectively (Khazaei, Ramachandran, et al., 2017). The FE of Hibiscus rosa-sinensis worked in synergy with taxol and cisplatin to decrease viability of triplenegative breast cancer cell line MDA-MB-231 (Nguyen et al., 2019).

It has been well documented that cancer cells have the ability to develop resistance to chemotherapeutic drugs by increasing ATPdependent bombs in the plasma membrane. Therefore, using chemotherapeutic resistant cells for assaying the effect of slower extracts is a useful approach. It has been reported that the concomitant exposure of the methanolic FE of Euryops pectinatus with doxorubicin significantly decreases the IC50 of the later in in vitro models of drug resistance cells (M Elkady et al., 2020).

In some cancers, the use of agents to promote apoptosis via the activation of cell death receptors is an alternative way of treatment. It is well known that cancer cells prevent the activation of apoptosis despite the expression of the receptor. Thus, the ethanolic FE of Thevetia peruviana stimulated apoptosis of cervical cancer HeLa cells triggered by TNFa or TRAIL, two ligands of death receptors, by activating caspase-3 and PARP. Notably, FE of T. peruviana diminished the expression of the anti-apoptotic protein survivin (Managit, Sakurai, and Saiki, 2017)

A FE containing essential oils of Pallines spinosa decreased cell viability of breast cancer cells while a minor effect was detected in immortalized mammary epithelial cells (Saleh et al., 2017). This effect was accompanied by a decrease of the anti-apoptotic protein $\mathrm{BCl}-2$ and an increase of the pro-apoptotic protein Bax

Flowers from Antirrhium majus are among the most popular edible flowers, frequently used from preparing foods and drinks. It has been shown that FE from red and yellow flowers contain phytochemicals that induce cell cycle arrest in G2/M phases in both lung and colon cancer cells in vitro (Seo et al., 2020). Moreover, both FE could inhibit cell invasion. These anticancer effects 
were observed with a minimal dose of $500 \mu \mathrm{g} /$ $\mathrm{mL}$ (Seo et al., 2020).

A research group in India has developed silver nanoparticles containing aqueous FE of Cassia fistula that could reduce cell viability of breast cancer MCF-7 cells (Remya et al., 2015).

While in vitro studies offer a preliminary view of the direct effect of novel compounds on cancer cells, results from in vivo pre-clinical studies bring a closer idea of their effect on human subjects. A few studies have been performed using in vivo protocols to determine the effect of FE on tumor development. Thus, the FE of the Peruvian Cordia lutea at doses of 250 and 500 $\mathrm{mg} / \mathrm{kg}$ for 5 months prevented the appearance of high-grade prostatic intraepithelial neoplasia in mice treated with cyproterone, testosterone, and $\mathrm{N}$-methylurea to induce prostate cancer (Rojas-Armas et al., 2020). Another group in India explored the effect of FE of Butea monosperrma on azoxymethane-induced colon cancer in rats where doses of $100-150 \mathrm{mg} / \mathrm{Kg}$ of the $\mathrm{n}$-butanol FE reduced the aberrant crypt formation (Subramaniyan, Polachi, and Mathan, 2016).

\section{Isolated compounds from flowers with anticancer effects}

From the pharmaceutical point of view, the study of pure isolated compounds brings more opportunities to develop of chemical techniques for their isolation or in vitro synthesis. Some compounds with anticancer activities have been isolated from flowers (Table 4). Nymphayol (25,26-dinorcholest-5-en-3b-ol) extracted from the chloroform fraction of the edible petals of Nymphaea stellate, is a sterol terpenoid that has been shown to promote cell death of the MCF7 breast cancer cells in a dose and timedependent manner while no effect was detected in normal cells (Al-Harbi et al., 2020). This effect of nymphayol was accompanied by significant changes in metabolic oxidative stress-related genes: up-regulation of gene expression of CYP1A, GSK3 3, GPX and TNF-a; and downregulation of NF-KB. In addition, it was observed that genes involved in cell cycle regulation were up-regulated by nymphaol exposure, such as Cdkn2A, pRB1 and p53. Moreover, nymphayol increased the gene expression of the proapoptotic genes Bax, Caspase-3, Caspase-9 while decreasing the anti-apoptotic genes $\mathrm{BCl}-2$.

In a brief study, 14 compounds were isolated from the flowers of Iris pseudopumila All of them showed an antiproliferative activity against two cancer cell lines. Two of these compounds scored over 95\% of inhibition: irisolidone and kaempferol-3-O- $\beta$-D-glucopyranoside (Conforti et al., 2009).

Several lanceolein chalcones have been isolated from Coreopsis lanceolata and tested for its anticancer effect in human colon cancer cells (Kim et al., 2019). Among them, two lanceoleins decreased cell viability by activating proapoptotic signals. Importantly, these compounds have almost no effect on cell viability of murine macrophage cells.

Butea monosperma is another plant that offers several compounds from its flowers that have anticancer properties. The sodium salt butrin demonstrated a more potent inhibition of cell survival than curcumin on colorectal cancer cells (Subramaniyan, Kumar, and Mathan, 2017) by inducing cell-cycle arrest at G1-S phase and increasing expression of p53. The same scientific group isolated isocoreopsin, butrin and isobutrin that inhibited cell survival of colon and liver cancer cells in vitro (Subramaniyan et al., 2016).

\section{CONCLUSION}

This review offers a brief overview of the studies of FE that had an anticancer activity against several types of human cancers. Although many of them show a great potential in in vitro assays, in vivo studies are required to validate their effect. Therefore, flowers from these plants may not only be beautiful to our eyes, but also possess compounds to fight cancer. 
Table 1

Ethnobotanical data of usage of flowers for cancer treatment

\begin{tabular}{|c|c|c|c|c|c|}
\hline Species & Community & & Preparation & Cancer & Ref. \\
\hline Cichorium endivia & $\begin{array}{l}\text { West } \\
\text { Palestine }\end{array}$ & Bank, & Infusion (oral) & $\begin{array}{l}\text { Stomach } \\
\text { colon }\end{array}$ & (Jaradat et al. 2016) \\
\hline Inula viscosa & $\begin{array}{l}\text { West } \\
\text { Palestine }\end{array}$ & Bank, & Decoction (oral) & $\begin{array}{l}\text { Kidney } \\
\text { bladder }\end{array}$ & (Jaradat et al. 2016) \\
\hline Matricaria aurea & $\begin{array}{l}\text { West } \\
\text { Palestine }\end{array}$ & Bank, & $\begin{array}{l}\text { Vapor inhalation } \\
\text { or decoction (oral) }\end{array}$ & $\begin{array}{l}\text { Lung, liver and } \\
\text { prostate }\end{array}$ & (Jaradat et al. 2016) \\
\hline $\begin{array}{l}\text { Onopordum } \\
\text { cynarocephalum }\end{array}$ & $\begin{array}{l}\text { West } \\
\text { Palestine }\end{array}$ & Bank, & Infusion (oral) & $\begin{array}{l}\text { Stomach } \\
\text { colon }\end{array}$ & (Jaradat et al. 2016) \\
\hline Trifolium philistaeum & $\begin{array}{l}\text { West } \\
\text { Palestine }\end{array}$ & Bank, & Decoction (oral) & $\begin{array}{l}\text { Ovary, breast and } \\
\text { non Hodgkin } \\
\text { lymphoma }\end{array}$ & (Jaradat et al. 2016) \\
\hline Ziziphus spina-christi & $\begin{array}{l}\text { West } \\
\text { Palestine }\end{array}$ & Bank, & Decoction (oral) & Lung & (Jaradat et al. 2016) \\
\hline Lavandula vera & Morocco & & Infusion (oral) & Breast and uterus & (Samouh et al. 2019) \\
\hline Eugenia aromatica & Morocco & & (No information) & Colon & (Samouh et al. 2019) \\
\hline
\end{tabular}


Table 2

Summary of the in vitro anticancer effects of FEs on cancer cells. Effective dose refers to the tested concentration that reached at least $50 \%$ of activity inhibition

\begin{tabular}{|c|c|c|c|c|c|c|}
\hline Species & Type of extract & Cell line & $\begin{array}{l}\text { Effective doses } \\
(\mu \mathrm{g} / \mathrm{mL})\end{array}$ & $\begin{array}{l}\text { Period of } \\
\text { treatment }\end{array}$ & Effect & Reference \\
\hline Allium atroviolaceum & Methanolic & $\begin{array}{l}\text { Human breast cancer MCF7, } \\
\text { MDA-MB-231 }\end{array}$ & $40-67$ & $48 \mathrm{~h}$ & Decrease cell viability & (Khazaei, Abdul Hamid, et al. 2017) \\
\hline Allium atroviolaceum & Methanolic & Human cervical HeLa & 50 & $48 \mathrm{~h}$ & Decrease cell viability & $\begin{array}{l}\text { (Khazaei, Ramachandran, et al. } \\
\text { 2017) }\end{array}$ \\
\hline Antirrhinum majus & Ethanolic & $\begin{array}{l}\text { H1299 human lung cancer } \\
\text { cells and HCT116 human } \\
\text { colon cancer cells }\end{array}$ & $100,500,1000$ & $72 \mathrm{~h}$ & $\begin{array}{l}\text { Decrease cell viability and } \\
\text { invasion }\end{array}$ & (Seo et al. 2020) \\
\hline \multirow[t]{3}{*}{ Butea monosperma } & \multirow[t]{3}{*}{ Aqueous } & Human hepatoma Huh7 & \multirow[t]{3}{*}{100,300 and 1000} & \multirow[t]{3}{*}{$48 \mathrm{~h}$} & Decrease cell viability & \multirow[t]{3}{*}{ (Choedon et al. 2010) } \\
\hline & & & & & $\begin{array}{l}\text { Normal cells not } \\
\text { significantly affected }\end{array}$ & \\
\hline & & $\begin{array}{l}\text { Immortalized mouse } \\
\text { hepatocyte CRL 2254 }\end{array}$ & & & & \\
\hline Echinacea purpurea & Ethanolic & $\begin{array}{l}\text { Human colorectal cancer HCT- } \\
116 \text { and Caco-2 }\end{array}$ & $50,100,200,1000$ & $48 \mathrm{~h}$ & Decrease cell viability & (Tsai et al. 2012) \\
\hline Euryops pectinatus & Defatted methanolic & $\begin{array}{ll}\text { Human breast MCF7/Dox } \\
\text { Human } & \text { leukemia } \\
\text { CEM/ADR5000 } & \end{array}$ & 5 & $72 \mathrm{~h}$ & $\begin{array}{l}\text { Decreased the IC50 of } \\
\text { doxorubicin }\end{array}$ & (M Elkady et al. 2020) \\
\hline $\begin{array}{l}\text { Hibiscus } \quad \text { rosa- } \\
\text { sinensis }\end{array}$ & Aqueous & $\begin{array}{l}\text { Human breast cancer MCF-7, } \\
\text { MDA-MB-231 }\end{array}$ & $2000-5000$ & $48-96 h$ & $\begin{array}{l}\text { Reduce cell viability } \\
\text { Synergize with taxol and } \\
\text { cisplatin in MDA-231 cells }\end{array}$ & (Nguyen et al. 2019) \\
\hline Iris pseudopumila & Methanolic & $\begin{array}{l}\text { Human lung carcinoma CORL- } \\
23 \\
\text { Human amelanotic melanoma } \\
\text { C32 }\end{array}$ & 100 & $48 \mathrm{~h}$ & $\begin{array}{l}\sim 40 \% \text { inhibition of } \\
\text { proliferation }\end{array}$ & (Conforti et al. 2009) \\
\hline Pallenis spinosa & Essential oils & $\begin{array}{l}\text { Human breast cancer MCF-7, } \\
\text { MDA-MB-231 }\end{array}$ & $0.1-5$ & $48 \mathrm{~h}$ & $\begin{array}{l}\text { Induce caspase- } \\
\text { depended apoptosis }\end{array}$ & (Saleh et al. 2017) \\
\hline $\begin{array}{l}\text { Rhododendron } \\
\text { arboreum }\end{array}$ & Methanolic & $\begin{array}{l}\text { Human cervical HeLa } \\
\text { Human breast MCF7 } \\
\text { Human lung A549 }\end{array}$ & 500 & $24 \mathrm{~h}$ & $\begin{array}{l}45-84 \% \text { inhibition of } \\
\text { proliferation }\end{array}$ & (Gautam et al. 2020) \\
\hline Thevetia peruviana & Ethanolic & Human cervical HeLa & $30-300$ & $24 \mathrm{~h}$ & $\begin{array}{l}\text { Increase sensitivity to } \\
\text { TNF-a or TRAIL-induced } \\
\text { cell death. }\end{array}$ & (Managit et al. 2017) \\
\hline
\end{tabular}

Table 3

Summary of anticancer effects of FEs tested in animals developing experimental tumors

\begin{tabular}{|c|c|c|c|c|c|c|}
\hline Species & Administration/dosis & $\begin{array}{l}\text { Period of } \\
\text { time }\end{array}$ & Model & Disease & Effect & Reference \\
\hline $\begin{array}{l}\text { Butea } \\
\text { monosperma }\end{array}$ & $\begin{array}{l}\text { Oral (daily, } 5 \text { days a } \\
\text { week)/100 - } 400 \\
\mathrm{mg} / \mathrm{Kg}\end{array}$ & 12 months & $\begin{array}{l}\text { HBV-related } \\
\text { transgenic } \\
\text { mouse model } \\
(\mathrm{X} 15-\mathrm{myc})\end{array}$ & $\begin{array}{l}\text { Hepatocellul } \\
\text { ar carcinoma }\end{array}$ & $\begin{array}{l}\text { Reduced serum VEGF } \\
\text { and alanine } \\
\text { aminotransferase } \\
\text { Increase apoptotic cells }\end{array}$ & $\begin{array}{l}\text { (Choedon et al. } \\
2010)\end{array}$ \\
\hline $\begin{array}{l}\text { Butea } \\
\text { monosperma }\end{array}$ & $\begin{array}{l}\text { Intraperitoneal } \\
\text { injection (daily, } 150 \\
\mathrm{mg} / \mathrm{Kg} \text { ) }\end{array}$ & 1 week & $\begin{array}{l}\text { Chemically } \\
\text { induced cancer } \\
\text { in rat }\end{array}$ & Colon cancer & $\begin{array}{l}\text { Reduced the } \\
\text { appearance of aberrant } \\
\text { crypt foci }\end{array}$ & $\begin{array}{l}\text { (Subramaniyan et } \\
\text { al. 2016) }\end{array}$ \\
\hline Cordia lutea & $\begin{array}{l}\text { Intraperitoneal } \\
\text { injection (daily)/250 } \\
-500 \mathrm{mg} / \mathrm{Kg}\end{array}$ & 5 months & $\begin{array}{l}\text { Chemically } \\
\text { induced cancer }\end{array}$ & $\begin{array}{l}\text { Prostate } \\
\text { cancer }\end{array}$ & Reduced PSA in blood & $\begin{array}{l}\text { (Rojas-Armas et al. } \\
\text { 2020) }\end{array}$ \\
\hline
\end{tabular}


Table 4

Summary of isolated compounds from flowers with anticancer effects

\begin{tabular}{|c|c|c|c|c|c|c|}
\hline Species & Compounds & Cell line & Doses & $\begin{array}{l}\text { Exposure } \\
\text { time }\end{array}$ & Effect & Reference \\
\hline $\begin{array}{l}\text { Butea } \\
\text { monosperma }\end{array}$ & $\begin{array}{l}\text { Sodium salt of } \\
\text { butrin }\end{array}$ & $\begin{array}{l}\text { Colorectal cancer } \\
\text { SW480 }\end{array}$ & $\begin{array}{l}10-120 \\
\mu \mathrm{M} / \mathrm{mL}\end{array}$ & $48 \mathrm{~h}$ & $\begin{array}{l}\text { Reduced cell } \\
\text { viability, increased } \\
\text { apoptosis }\end{array}$ & $\begin{array}{l}\text { (Subramaniyan et al. } \\
\text { 2017) }\end{array}$ \\
\hline $\begin{array}{l}\text { Butea } \\
\text { monosperma }\end{array}$ & $\begin{array}{l}\text { Isobutrin } \\
\text { Butrin } \\
\text { Isoreopsin }\end{array}$ & $\begin{array}{l}\text { Human colon } \\
\text { cancer HT29 } \\
\text { Hepatocarcinoma } \\
\text { HepG2 }\end{array}$ & $\begin{array}{l}100-750 \\
\mu \mathrm{M} / \mathrm{mL}\end{array}$ & $48 \mathrm{~h}$ & $\begin{array}{l}\text { Reduced cell } \\
\text { viability }\end{array}$ & $\begin{array}{l}\text { (Subramaniyan et al. } \\
\text { 2016) }\end{array}$ \\
\hline $\begin{array}{l}\text { Coreopsis } \\
\text { lanceolata }\end{array}$ & Lanceoleins & $\begin{array}{l}\text { Human colon } \\
\text { cancer HCT15 }\end{array}$ & $\sim 40 \mu \mathrm{M}$ & $24 \mathrm{~h}$ & $\begin{array}{l}\text { Trigger apoptosis, } \\
\text { no effect on } \\
\text { macrophage cell line } \\
\text { RAW264.7 }\end{array}$ & (Kim et al. 2019) \\
\hline Iris pseudopumila & $\begin{array}{l}\text { Irisolidone, } \\
\text { kaempferol-3- } \\
\text { O- } \beta \text {-D- } \\
\text { glucopyranosid } \\
\text { e }\end{array}$ & $\begin{array}{l}\text { Human lung } \\
\text { carcinoma CORL- } \\
23 \\
\text { Human amelanotic } \\
\text { melanoma C32 }\end{array}$ & $100 \mu \mathrm{M}$ & $48 \mathrm{~h}$ & $\begin{array}{l}\sim 90 \% \text { inhibition of } \\
\text { proliferation in vitro }\end{array}$ & (Conforti et al. 2009) \\
\hline Lonicera japonica & Pectin & $\begin{array}{l}\text { Human pancreatic } \\
\text { cancer BxPC-3 and } \\
\text { PANC-1, and } \\
\text { normal pancreatic } \\
\text { cells LO2 }\end{array}$ & $\begin{array}{l}16-125 \\
\mu \mathrm{g} / \mathrm{mL}\end{array}$ & $72 \mathrm{~h}$ & $\begin{array}{l}\text { Reduced cell } \\
\text { viability but not in } \\
\text { normal cells }\end{array}$ & (Lin et al. 2016) \\
\hline
\end{tabular}

\section{BIBLIOGRAPHIC REFERENCES}

Al-Harbi, Laila Naif, Pandurangan Subash-Babu, Manal Abdulaziz Binobead, Maha Hussain Alhussain, Sahar Abdulaziz AlSedairy, Amal A. Aloud, and Ali A. Alshatwi. (2020) "Potential Metabolite Nymphayol Isolated from Water Lily (Nymphaea Stellata) Flower Inhibits MCF-7 Human Breast Cancer Cell Growth via Upregulation of Cdkn2a, PRb2, P53 and Downregulation of PCNA MRNA Expressions." Metabolites 10(7). DOI: 10.3390/metabo10070280.

Al-Oqail, Mai Mohammad, Amina El-Shaibany, Ebtesam Al-Jassas, Ebtesam Saad AlSheddi, Shaza Mohamed Al-Massarani, and Nida Nayyar Farshori. (2016). "In Vitro AntiProliferative Activities of Aloe Perryi Flowers Extract on Human Liver, Colon, Breast, Lung, Prostate and Epithelial Cancer Cell Lines." Pakistan Journal of Pharmaceutical Sciences $\quad 29(2 \quad$ Suppl):723-29.

Arrondeau, Jennifer, Hui K. Gan, Albiruni R. A. Razak, Xavier Paoletti, and Christophe Le Tourneau. (2010). "Development of Anti-Cancer
Drugs." Discovery Medicine 10(53):355-62. Disponible en: https://elib.tips/edoc/2004landes-bioscience-do-not-distributeanalysis-of-fda-approved-anticancer-drugsreveals-the-future-of-cancer-therapy.html

Blagosklonny, Mikhail V. (2004). "Analysis of FDA Approved Anticancer Drugs Reveals the Future of Cancer Therapy." Cell Cycle (Georgetown, Tex.) 3(8):1035-42.

Bray, Freddie, Jacques Ferlay, Isabelle Soerjomataram, Rebecca L. Siegel, Lindsey A. Torre, and Ahmedin Jemal. 2018. "Global Cancer Statistics (2018)): GLOBOCAN Estimates of Incidence and Mortality Worldwide for 36 Cancers in 185 Countries." CA: A Cancer Journal for Clinicians 68(6):394-424. DOI: 10.3322/caac.21492.

Chen, Szu-Jung, Yuan-Chiang Chung, HanLung Chang, Hsin-Ping Chang, Jui-Ling Chou, Chih-Cheng Lin, Chih-Hsien Chen, and Chih-Ping Hsu. (2020. "Synergistic Effect of Combined Treatment with Longan Flower 
Extract and 5-Fluorouracil on Colorectal CancerCells."Nutrition and Cancer 72(2):20917. DOI: 10.1080/01635581.2019.1622739.

Choedon, Tenzin, Surendra Kumar Shukla, and Vijay Kumar. (2010). "Chemopreventive and Anti-Cancer Properties of the Aqueous Extract of Flowers of Butea Monosperma." Journal of Ethnopharmacology 129(2):20813. DOl: $10.1016 / j . j e p .2010 .03 .011$.

Conforti, Filomena, Federica Menichini, Daniela Rigano, and Felice Senatore. (2009). "Antiproliferative Activity on Human Cancer Cell Lines after Treatment with Polyphenolic Compounds Isolated from Iris Pseudopumila Flowers and Rhizomes." Zeitschrift Fur Naturforschung. C, Journal of Biosciences 64(7-8):49094. DOI: 10.1515/znc-2009-7-804.

Gautam, Vandana, Anket Sharma, Saroj Arora, Renu Bhardwaj, Ajaz Ahmad, Bilal Ahamad and Parvaiz Ahmad. (2020). "In-Vitro Antioxidant, Antimutagenic and Cancer Cell GrowthInhibitionActivitiesofRhododendron Arboreum Leaves and Flowers." Saudi Journal of Biological Sciences 27(7):178896. DOI: $10.1016 / j . j j b s .2020 .01 .030$.

Goodman, Jordan, Vivien Walsh, and Professor in Innovation Management Manchester Business School Vivien Walsh. (2001). The Story of Taxol: Nature and Politics in the Pursuit of an Anti-Cancer Drug. Cambridge University Press.

Hanahan, Douglas, and RobertA. Weinberg.(2011). "Hallmarks of Cancer: The next Generation." Cell 144(5):646-74. DOl: $\quad$ 10.1016/j.cell.2011.02.013.

Jaradat, Nidal Amin, Rowa Al-Ramahi, Abdel Naser Zaid, Ola Ibrahim Ayesh, and Ahmad Mustafa Eid. (2016). "Ethnopharmacological Survey of Herbal Remedies Used for Treatment of Various Types of Cancer and Their Methods of Preparations in the West Bank-Palestine." BMC Complementary and Alternative Medicine 16(1):93. DOl: $\quad$ 10.1186/s12906-016-1070-8.

Khazaei, Somayeh, Roslida Abdul Hamid, Vasudevan Ramachandran, Norhaizan Mohd Esa, Ashok Kumar Pandurangan, Fatemeh Danazadeh, and Patimah Ismail. (2017). "Cytotoxicity and Proapoptotic Effects of Allium Atroviolaceum Flower Extract by Modulating Cell Cycle Arrest and Caspase-Dependent and P53Independent Pathway in Breast Cancer Cell Lines." Evidence-Based Complementary and Alternative Medicine: ECAM 2017:1468957. DOI: 10.1155/2017/1468957.

Khazaei, Somayeh, Vasudevan Ramachandran, Roslida Abdul Hamid, Norhaizan Mohd Esa, Ali Etemad, Sara Moradipoor, and Patimah Ismail. (2017). "Flower Extract of Allium Atroviolaceum Triggered Apoptosis, Activated Caspase-3 and down-Regulated Antiapoptotic Bcl-2 Gene in HeLa Cancer Cell Line."Biomedicine \& Pharmacotherapy $=$ Biomedecine \& Pharmacotherapie 89:1216 26. DOI: 10.1016/j.biopha.2017.02.082.

Kim, Hyoung-Geun, Hyun-Ji Oh, Jung-Hwan Ko, Hae Seong Song, Yeong-Geun Lee, Se Chan Kang, Dae Young Lee, and Nam-In Baek. (2019). "Lanceoleins A-G, Hydroxychalcones, from the Flowers of Coreopsis Lanceolata and Their Chemopreventive Effects against Human Colon Cancer Cells." Bioorganic Chemistry 85:274-81. DOI: $\quad$ 10.1016/j.bioorg.2019.01.003.

Lin, Liyan, Peipei Wang, Zhenyun Du, Wucheng Wang, Qifei Cong, Changping Zheng, Can Jin, Kan Ding, and Chenghao Shao. (2016). "Structural Elucidation of a Pectin from Flowers of Lonicera Japonica and Its Antipancreatic Cancer Activity."International JournalofBiologicalMacromolecules88:13037. DOI: 10.1016/j.ijbiomac.2016.03.025. M Elkady, Wafaa, Iriny M Ayoub, Yousra AbdelMottaleb, Mohamed F. ElShafie, and Michael Wink. (2020). "Euryops Pectinatus L. Flower Extract Inhibits P-Glycoprotein 
and Reverses Multi-Drug Resistance in Cancer Cells: A Mechanistic Study." Molecules (Basel, Switzerland) 25(3). DOI: $\quad 10.3390 /$ molecules25030647.

Managit, Chittima, Hiroaki Sakurai, and Ikuo Saiki. (2017). "Ethanolic Extract of Thevetia Peruviana Flowers Enhances TNF-a and TRAIL-Induced Apoptosis of Human Cervical Cancer Cells via Intrinsic and Extrinsic Pathways." Oncology Letters 13(4):2791-98. DOI: 10.3892/ol.2017.5748.

Nguyen, Christopher, Kiruthika Baskaran, Alaina Pupulin, Ivan Ruvinov, Ola Zaitoon, Sahibjot Grewal, Benjamin Scaria, Ali Mehaidli, Caleb Vegh, and Siyaram Pandey. (2019). "Hibiscus Flower Extract Selectively Induces Apoptosis in Breast Cancer Cells and Positively Interacts with Common Chemotherapeutics." BMC Complementary and Alternative Medicine 19(1):98. DOI: 10.1186/s12906-019-2505-9.

Remya, R. R., S. R. Radhika Rajasree, L. Aranganathan, and T. Y. Suman. (2015). "An Investigation on Cytotoxic Effect of Bioactive AgNPs Synthesized Using Cassia Fistula Flower Extract on Breast Cancer Cell MCF-7." Biotechnology Reports (Amsterdam, Netherlands) 8:110-15. DOl: 10.1016/j.btre.2015.10.004.

Rojas-Armas, Juan Pedro, Jorge Luis ArroyoAcevedo, José Manuel Ortiz-Sánchez, Miriam Palomino-Pacheco, Oscar HerreraCalderón, James Calva, Agustín Rojas-Armas, Hugo Jesús Justil-Guerrero, Américo CastroLuna, and Julio Hilario-Vargas. (2020)."Cordia Lutea L. Flowers: A Promising Medicinal Plant as Chemopreventive in Induced Prostate Carcinogenesis in Rats." Evidence-Based Complementary and Alternative Medicine 2020:1-8. DOI: 10.1155/2020/5062942.

Saleh, Ayman M., Mahmoud A. Al-Qudah, Amre Nasr, Sayed A. Rizvi, Anwar Borai, and Mustafa Daghistani. (2017). "Comprehensive Analysis of the Chemical Composition and In Vitro Cytotoxic Mechanisms of
Pallines Spinosa Flower and Leaf Essential Oils Against Breast Cancer Cells." Cellular Physiology and Biochemistry: International Journal of Experimental Cellular Physiology, Biochemistry, and Pharmacology 42(5):2043-65. DOI: 10.1159/000479900.

Samouh, Yassine, Asmaa Lemrani, Hajar Hajar, Jaoud Mohamad, and Amal Ait Haj Said. (2019). "Ethnopharmacological Study of Herbal Medicines Used to Treat Cancer in Morocco."The Journal of Phytopharmacology 8(3):135-41.DOl: 10.31254/phyto.2019.8309.

Seo, Jina, Jungjae Lee, Hyi Young Yang, and Jihyeung Ju.( 2020). "Antirrhinum Majus L. Flower Extract Inhibits Cell Growth and Metastatic Properties in Human Colon and Lung Cancer Cell Lines." Food Science \& Nutrition 8(11):6259-68. DOl: $\quad 10.1002 / f s n 3.1924$.

Subramaniyan, Boopathi, Vijay Kumar, and Ganeshan Mathan. (2017). "Effect of Sodium SaltofButrin, aNovelCompoundlsolatedfrom Butea Monosperma Flowers on Suppressing the Expression of SIRT1 and Aurora B KinaseMediated Apoptosis in Colorectal Cancer Cells." Biomedicine \& Pharmacotherapy = Biomedecine \& Pharmacotherapie 90:40213. DOI: 10.1016/j.biopha.2017.03.086.

Subramaniyan, Boopathi, Navaneethakrishnan Polachi, and Ganeshan Mathan. (2016). "Isocoreopsin: An Active Constituent of n-Butanol Extract of Butea Monosperma Flowers against Colorectal Cancer (CRC)." Journal of Pharmaceutical Analysis 6(5):31825. DOI: 10.1016/j.jpha.2016.04.007.

Sun, Jingchun, Qiang Wei, Yubo Zhou, Jingqi Wang, Qi Liu, and Hua Xu. 2017."A Systematic Analysis of FDA-Approved Anticancer Drugs." BMC Systems Biology 11(Suppl 5):87. DOI: 10.1186/s12918-017-0464-7.

Tan, G., C. Gyllenhaal, and D. D. Soejarto. (2006)."Biodiversity as a Source of Anticancer Drugs." Current Drug Targets 7(3):265-77. DOl: $\quad 10.2174 / 138945006776054942$. 
Tsai, Yu-Ling, Chien-Chih Chiu, Jeff Yi-Fu Chen, Kung-Chi Chan, and Sheng-Dun Lin. (2012). "Cytotoxic Effects of Echinacea Purpurea Flower Extracts and Cichoric Acid on Human Colon Cancer Cells through Induction of Apoptosis." Journal of Ethnopharmacology 143(3):91419. DOl: $10.1016 /$ j.jep.2012.08.032.

Wani, M. C., H. L. Taylor, M. E. Wall, P. Coggon, and A. T. McPhail. (1971). "Plant Antitumor Agents. VI. The Isolation and Structure of Taxol, a Novel Antileukemic and Antitumor Agent from Taxus Brevifolia." Journal of the American Chemical Society 93(9):2325-27. DOI: 10.1021/ja00738a045. 